\title{
Characterization of Leachate from Different Landfills Sites of Morocco and Spain: A Comparative Study
}

\section{El Bied Oumaima,}

Bioscience Laboratory, University of science and technology Mohammedia, Hassan II University of Casablanca, Morocco

Research group GARSA, Universidad Politécnica de Cartagena, Spain Angel Faz Cano, Jose Alberto Acosta Aviles, Research group GARSA, Universidad Politécnica de Cartagena, Spain

\section{Taoufiq Fechtali,}

Bioscience Laboratory, University of science and technology Mohammedia, Hassan II University of Casablanca, Morocco

Doi: 10.19044/esj.2019.v15n18p183 URL:http://dx.doi.org/10.19044/esj.2019.v15n18p183

\section{Abstract}

The socio-economic activities in Morocco and Spain as well as all the other countries around the world involving population growth and changes in consumption behavior have generated a substantial and important solid waste production. The decomposition of waste by microorganisms in landfills generates soluble compounds, which under the leaching action and water infiltration meteorites come to mix together forming "leachate juices". Its composition varies widely depending on the age of the landfill and the type of waste it contains. The latter usually contains dissolved and suspended material. This study aims to characterize the physicochemical properties and evaluate the mineral and organic compounds of different leachates. It is worthy to note that this physicochemical characterization is arbitrary because those landfills will soon be equipped with an elimination center and treatment. The following objectives of this paper have been set for this work; on one hand, to determine the qualitative characteristics aspects of leachates that are essential for characterizing the pollutant load and, thus, estimating the risks that these leachates pose to the water quality of the surrounding groundwater. On the other hand, it aims to propose a cost effective and efficient leachates treatment processes and also serves as a stepping stone reference for future leachate research. The desired process aims at obtaining a very significant reduction in the organic load of the leachate and thus could be replicated in other current and future releases. To achieve this characterization, we carried out a series of leachate sampling from different regions in Morocco 
(Casablanca and Marrakech) and Spain (ULEA and Orihuela). This sampling was carried out for the purpose of making a comparison between the evolutions of their qualities, and it also allows us to know the statue of those landfills.

Keywords: Physical chemical characterization, Cost effective and efficient treatments, Leachate, Morocco, Spain

\section{Introduction}

Solid and urban waste produced by the municipality of Casablanca, Marrakech, ULEA, and Orihuela are usually transported to an uncontrolled landfills, wild dump in an area of hectares on the municipality outskirts. Unfortunately, these landfills do not possess any leachate treatment procedure.

Leachate is a brownish effluent liquid produced under the combined action of rainwater and fermentation which is collected and stored in leachate ponds. It is a very toxic and chronic effluent which contains a high load of organic matter, mineral, toxic and bacteriological pollution. Untreated leachates can leach into groundwater or contaminate surface water and thus contribute to water pollution.

Therefore, the need to find suitable techniques for the treatment of these leachates in relation to the initial conditions and to the requirements of the receiving environment remains an unavoidable obligation.

This paper focuses on making a physicochemical characterization and evaluating the mineral and organic states of this leachate, and it also serves as a reference for future researches in leachate.

To achieve this characterization, we conducted a leachate sampling in March 2018. The physicochemical analysis performed on those samples for that same period revealed: High levels of Nitrates $\left(\mathrm{NO}_{3^{-}}=180 \mathrm{mg} / \mathrm{L}\right.$, $179 \mathrm{mg} / \mathrm{l})$ in the leachate in Morocco and low level in Spain's leachate $(20.3 \mathrm{mg} / \mathrm{l})$; High levels of Ammonium for both countries leachates $\left(\mathrm{NH}_{4}=\right.$ $4 \mathrm{~g} / 1,4.34 \mathrm{~g} / \mathrm{l}$ and 2.5g/l); Very high levels of Nitrite in Morocco's leachate $\left(\mathbf{N O}^{2-}=435.93 \mathrm{mg} / 1,916.85 \mathrm{mg} / \mathrm{l}\right)$ and very low level in Spain's leachate $\left(\mathbf{N O}^{2-}=1.4 \mathrm{mg} / \mathrm{l}\right)$; Very high levels of Sodium in all the four landfills $(\mathrm{Na}=$ $2.36 \mathrm{~g} / \mathrm{l}, 3.16 \mathrm{~g} / \mathrm{l}, 5.18 \mathrm{~g} / \mathrm{l})$.

This mineral concentration is translated by a high electrical conductivity that reaches the value of $60 \mu \mathrm{S} / \mathrm{cm}$. Recorded COD values range from 49 to $107 \mathrm{~g} \mathrm{O} 2 / \mathrm{L}$. Those of BOD5 are between 600 and 3500mg O2/L. The values of the ratio DBO5/COD oscillate between 0.012 and 0.003 . These verify the anaerobic character level state of discharge and the likeliness of the aquifer water contamination. Thus, the hydrogen potential $(\mathrm{pH})$ ranges are between 6.3 and 8.16. 
This paper is a part of a thesis in cotutelle between the two universities (Spain and Morocco), which was one of the reasons to choose the different landfills from the two countries and also the common points between the regions (climatology, mode of consumption ...).

\section{Material and Methods Used \\ Presentation of the Study Areas}

The studied areas are Ulea and Orihuela in Spain, Casablanca and Marrakech in Morocco. Ulea is in Murcia region that is located between the regions of Andalusia and Castile-La Mancha. The region of Murcia occupies an area of $11,317 \mathrm{~km}^{2}$ (2.2\% of the total surface area of Spain), bordering the province of Albacete in the North, the province of Alicante in the East, the provinces of Granada, Albacete and Almería in the West, and the Mediterranean in the South-East.

Orihuela is a city located at the feet of the Sierra de Orihuela mountains in the province of Alicante, Spain. It occupies an area of 367.19 $\mathrm{km}^{2}$ and extends all the way down to the Mediterranean coast, west of Torrevieja. In addition, it had a population of 33,943 inhabitants.

Casablanca is the largest city in Morocco and also in the Maghreb, located in the central-western part of Morocco, bordering the Atlantic Ocean. Casablanca is one of the largest and most important cities in Africa, both economically and demographically. The city has a population of about 3.35 million in the urban area and over 6.8 million in the Casablanca-Settat region.

Marrakech is the capital city of the mid-southwestern region of Marrakesh-Safi. It is located to the north of the foothills of the snow-capped Atlas Mountains and is situated $239 \mathrm{~km}^{2}$ south of Casablanca with a population of 928,850 inhabitants.

\section{Sampling and Data Analysis Methods}

Leachate samples were collected from the sanitary landfills of Casablanca, Marrakech, Orihuela, and Ulea. The sampling period was in March 2018. The leachates were collected in 15L plastic bottles previously washed with nitric acid and then with distilled water (Rodier, et al., 2009). It was finally transported to the UPCT laboratory, stored at $4{ }^{\circ} \mathrm{C}$ and subsequently characterized.

Temperature (T), electrical conductivity (EC), and $\mathrm{pH}$ were measured in situ SM (Suspended matter) with membrane filtration; The chloride concentrations $\left(\mathrm{Cl}^{-}\right)$, sulphates $\left(\mathrm{SO}_{4}{ }^{2-}\right)$, calcium $\left(\mathrm{Ca}^{++}\right)$, magnesium $\left(\mathrm{Mg}^{++}\right)$ Sodium $\left(\mathrm{Na}^{+}\right)$, Potassium $\left(\mathrm{K}^{+}\right)$, Nitrite $\left(\mathrm{NO}^{2-}\right)$ and Nitrate $\left(\mathrm{NO}^{3-}\right)$, using ion chromatography (Metrohm, model 861) and spectrophotometer flame method. 
The total nitrogen (NT) has been estimated according to the Kjeldhal method (Kjeltec system 1002 Distilling unit), Ammonia nitrogen (N-NH4 +), by distillation in basic medium. It was collected in acid medium and automatic titration. COD uses the kits NANOCOLOR Test 0-28, and Biological demand in oxygen (BOD5) was measured by a BOD-meter (WTW D 82362 Weilheim). Heavy metals (Copper, Iron, Manganese and Zinc) was also measured through the direct measurement in atomic absorption Perkin Elmer AA-Analyst 800.

\section{Results and Discussion}

The characteristic values of the main physicochemical parameters for the leachates samples under this study are presented in Table 1.

Table 1. Physcial chemical characterisations of the four lecheates

\begin{tabular}{lllll} 
& Casablanca & Marraekch & Ulea & Orihuela \\
\hline $\mathrm{pH}$ & 7.6 & 7.5 & 7.6 & 8.16 \\
\hline $\mathrm{Ec}(\mathrm{ms} / \mathrm{cm})$ & 23.5 & 43.1 & 55.52 & 60 \\
\hline $\mathrm{SM}(\mathrm{g} / \mathrm{l})$ & 9.4 & 40.6 & 3.640 & 52.9 \\
\hline $\mathrm{BOD} 5(\mathrm{mg} / \mathrm{l})$ & 600 & 3250 & 31.1 & 3500 \\
\hline $\mathrm{COD}(\mathrm{g} / \mathrm{l})$ & 49 & 89 & 19.53 & 107 \\
\hline $\mathrm{DBO} / \mathrm{COD}$ & 0.012 & 0.03 & 0.001 & 0.03 \\
\hline $\mathrm{NH} 4+(\mathrm{mg} / \mathrm{l})$ & 2505.066 & 4345.62 & 4000 & 4100 \\
\hline $\mathrm{NK}(\mathrm{g} / \mathrm{Kg})$ & 4.0983 & 4.7129 & 4.99 & 4.66 \\
\hline $\mathrm{No} 2-(\mathrm{mg} / \mathrm{l})$ & 435.93 & 916.85 & 1.4 & - \\
\hline $\mathrm{NO} 3-(\mathrm{mg} / \mathrm{l})$ & 180.61 & 179.33 & 20.3 & - \\
\hline $\mathrm{COT}(\mathrm{g} / \mathrm{kg})$ & 18.145 & 24.260 & 22.5 & - \\
\hline $\mathrm{SO} 4 \mathrm{mg} / \mathrm{l})$ & 3112.18 & 3466.86 & 5410 & 4000 \\
\hline $\mathrm{Na}(\mathrm{mg} / \mathrm{l})$ & 741.14 & 1262,63 & 860 & 1109 \\
\hline $\mathrm{Mg}(\mathrm{mg} / \mathrm{l})$ & 2369.05 & 3167.97 & 5179.83 & 1211.00 \\
\hline $\mathrm{Ca}(\mathrm{mg} / \mathrm{l})$ & 241.86 & 349.14 & 366 & 284.200 \\
\hline $\mathrm{K}(\mathrm{mg} / \mathrm{l})$ & 1227.91 & 1883.41 & 2100.3 & 5000 \\
\hline $\mathrm{Zn}(\mathrm{mg} / \mathrm{l})$ & 2052.26 & 2938.82 & 2300.6 & 2888.5 \\
\hline $\mathrm{Cu}(\mathrm{mg} / \mathrm{l})$ & 0.9466 & 45.9707 & 0.60 & 0.32 \\
\hline $\mathrm{Fe}(\mathrm{mg} / \mathrm{l})$ & 0.1614 & 1.4607 & 1.13 & 0.23 \\
\hline $\mathrm{Mn}(\mathrm{mg} / \mathrm{l})$ & 2199.68 & 474.6063 & 520.36 & 686.6 \\
\hline 29.6827 & 15.5117 & 14.38 & 10.29
\end{tabular}

\section{Abiotic Parameters \\ Leachates Color}

The brownish black color and the strong noisome smell of the four studied landfills leachates may present the first pollution indicator, and also a strong mineralization by chemical elements. 


\section{Potential Hydrogen}

The average values of the $\mathrm{pH}$ are respectively 7.6 for Casablanca and 7.55 for Marrakech, and 7.6 for Ulea and 8.16 for Orihuela. The values obtained from the four leachates show that in the four landfills, the volatile organic compounds values are very low (Tchonaboglus, et al., 1993).

\section{Suspended Matter}

The suspended matter (SM) is respectively $9.4 \mathrm{~g} / \mathrm{L}$ for Casablanca and 40.6 g / L for Marrakech, and 3.64g/l for Ulea and $52.9 \mathrm{~g} / \mathrm{l}$ for Orihuela.

The $\mathrm{pH}$ and the $\mathrm{SM}$ values show, on the one hand, the basic character of leachates from the studied landfills and, on the other hand, their high mineral and organic charge (Aluko, et al., 2003).

\section{Electrical Conductivity}

The studied samples of the four different landfills present very important values of conductivity. The average electrical conductivity is of the order of $23.5 \mathrm{mS} / \mathrm{cm}$ for Casablanca, $43.1 \mathrm{mS} / \mathrm{cm}$ for Marrakech, 55.52 $\mathrm{mS} / \mathrm{cm}$ for Ulea, and $60 \mathrm{mS} / \mathrm{cm}$ for Orihuela. Those values indicate the strong mineralization of the landfills leachates. Also, those high values coincide with high concentrations of chloride, sodium, and sulphates recorded in the four landfills.

\section{Chloride and Sulfate}

This high mineralization is similarly linked to the following parameters; the high chlorides values $(3112 \mathrm{mg} / 1,3466 \mathrm{mg} / 1,5410 \mathrm{mg} / \mathrm{l}$, and $4000 \mathrm{mg} / \mathrm{l})$, and sulphates values $(741 \mathrm{mg} / \mathrm{l}, 1262 \mathrm{mg} / \mathrm{l}, 860 \mathrm{mg} / \mathrm{l}$, and 1109 $\mathrm{mg} / \mathrm{l})$. Those high concentrations coincide with the high values of electrical conductivity which confirms that the conductivity is largely determined by chloride ions and sulfate ions.

This high mineralization is mainly attributed to the ions chlorides, calcium, sulfates, and magnesium. Khattabi (2002) showed the relationship between the high conductivity and chlorides contents on the site of Etueffort.

However, the presence of sulfites is explained by the acetogenic phase or the sulfite-reducing bacteria that reduce sulfide to sulfates.

\section{Heavy Metals}

The values in Table 1 clearly shows a low metal load (from 0.161 to $1.46 \mathrm{mg} / \mathrm{l}$ for copper, $520 \mathrm{mg} / 1$ to $2199 \mathrm{mg} / 1$ for iron, 10 to $26 \mathrm{mg} / \mathrm{l}$ for Manganese, and from 0.32 to 0.94 for zinc) with the exception of the Marrakech landfill, which has a high content of $\mathrm{Zn} \mathrm{(45} \mathrm{mg} \mathrm{/} \mathrm{1).}$

This abnormal value is due to the fact that the landfill still continues to receive waste that contains zinc, especially industrial waste that is unloaded 
in the raw state and mixed with household waste. Indeed, it would be better to review the evolution of this heavy metal element within the year.

The metallic composition of the four leachates is typical of landfills with a dominant domestic character and that their content of heavy metals remains, however, weak compared to that of leachates of industrial waste landfills. The metal load, especially zinc, for the Marrakesh landfill poses a huge risk for neighboring ecosystems.

\section{Biotic Parameters}

\section{Chemical Oxygen Demand (COD)}

Regarding the organic charge, the average contents of COD for Casablanca, Marrakech, Ulea, and Orihuela are respectively $49 \mathrm{mg} / 1,89 \mathrm{mg} / \mathrm{l}$, $19.5 \mathrm{mg} / \mathrm{l}$, and $107 \mathrm{~g} / \mathrm{l}$. The COD represents the amount of oxygen consumed by oxidizable materials chemically contained in water. It is the representation of most organic compounds and salts oxidizable minerals (Bechac, J.P. et al., 1984). The high recorded values of COD indicate a very high organic load which shows that the oxygen is reducing in those effluents.

Furthermore, the absence of dissolved oxygen in the leachate and the low values of the oxidation-reduction potential indicate that the phenomenon of anaerobiosis is predominant in the four landfills. Indeed, oxygen is strongly stressed for the degradation of organic matter and the oxidation of minerals present in the effluents.

The values obtained at the level of the polluting load, expressed by COD, are comparable to those reported by El Khalmichi, et al. (1997) Flap. This difference could be related to the age, nature, and quantity of waste as well as the various climatic factors such as rainfall, the humidity of the air, and the temperature. According to Christensen, et al. (2001), these different factors are at the base of the variability of polluting loads.

\section{Biological Oxygen Demand BOD5}

BOD5 is an indicator of organic water pollution which expresses the level of biodegradability of the effluent (Bechac, et al., 1984). BOD5 for Casablanca, Marrakech, Ulea, and Orihuela are respectively 300mg/1, 3250 $\mathrm{mg} / \mathrm{l}, 3.1 \mathrm{mg} / \mathrm{l}$, and 3500mg/1.

The concentrations of the BOD5 in the four leachates are very different, but they remain in the norms of stabilized leachates (Ntampou, 2006). This difference is related to the nature of the waste present at each discharge. Truly, it was found that the BOD5 is very low in the leachates of the Ulea landfill due to a more advanced maturation of waste in this landfill. 


\section{BOD5/COD Rapport}

Organic fractions (BOD5/COD) provide information and describe the degree of biodegradability of organic molecules and the relative age of the studied leachates. In this context, the (BOD5 / COD) ratio is of 0.01875 for Casablanca, 0.03 for Marrakech, 0.001 for Ulea, and 0.03 for Orihuela. This low ratio indicates that the high concentration of non-biodegradable organic compounds is highly difficult to be biologically degraded (Ntampou, 2006). Therefore, the leachate and the landfill studied are mature leachate (Chian, 1977).

These values show that all the leachates from the different landfills are stabilized leachates.

Thus, according to Amokrane (1994):

- BOD5 / COD is greater than 0.5: the leachate is qualified as young;

- BOD5 / COD is between 0.1 and 0.5: the leachate is intermediate;

- BOD5 / COD is less than 0.1: leachate is stabilized;

Consequently, it appears that landfills are very old and that they currently go through the methanogenesis stage (BOD5 / COD is less than 0.1). We can conclude that landfill leachate has an old and stabilized leachate, characterized by less biodegradability and a complex organic load, and that the waste is deemed to be stabilized.

The values of the ratio calculated for the four landfills confirm the stabilization of waste with a low presence of volatile fatty acids (VFA). Indeed, the value of 00.1 and the basic $\mathrm{pH}$ (7.6 on average), measured in the leachate of the Ulea dump, reflect that the leachate of this landfill is the most old and stabilized leachate of the four landfills. Hence, this was characterized by less biodegradability and a more or less complex organic load.

\section{Conclusion}

The characterization of leachates generated by the uncontrolled landfills of the four cities has shown that those are mature leachates, with high mineral and organic load. Organic load is translated by the high values of COD and BOD5. On the other hand, as for the mineral pollution, it is translated by the high values $\mathrm{NH}_{4}(\mathrm{mg} / \mathrm{l}), \mathrm{NO}^{3-}(\mathrm{mg} / \mathrm{l})$, and PO42- (mg/ 1).

At the end of this study, it appears that all the studied landfills enter a methanogenic phase (BOD5 / COD $=0.03,0.001,0.01)$ which is carried out by strict anaerobic microorganisms. They are thus considered as stabilized discharges.

The leachates are characterized by a strong organic load with a COD exceeding the reference value, and it has a low load of degradable material consisting mainly of humic substances (fulvic and humic acids). 
Mineral pollution is translated by high values exceeding the reference limit values: NH4+ (4345mg / 1), NO2- (916mg / 1), NO3- (180mg / 1) and $\mathrm{Na}+(5179 \mathrm{mg} / 1)$, which is indicative of the importance of the mineral and organic fillers described above. This mineral pollution is translated by a high conductivity which reaches a very high value. Those landfills present potential risks of environmental degradation and should be rehabilitated immediately (Tahiri, et al., 2014). The need to find suitable techniques for the treatment of those leachates in relation to the initial conditions and the requirements of the receiving environment is an obligation.

\section{References:}

1. Aluko, O.O., Sridhar, M.K.C. \& Oluwande, P.A. (2003). Characterization of leachates from a municipal solid waste landfill site in Ibadan, Nigeria. J. Environ. Health Res. 2(1):32-37.

2. Amokrane, A. (1994). Epuration des lixiviats de décharges. Prétraitement par coagulation-floculation. Traitement par osmose inverse. Post-traitement par incinération. Thèse de Doctorat, INSA de Lyon, France, 286 pages

3. Bechac, J.P., Boutin, P. \& Nuer, P. (1984), Traitement des eaux usées. Ed. Eyrolls. Paris.

4. Christensen, P. (2001). Biogeochemistry of landfill leachate plumes. Application Geochemistry 16, 659-718.

5. El Khamlichi, M.A., Lakrabni, S., Kabbaj, M., Jarby, E. \& Kouhen, M. (1997). Etude d'impact de la décharge d'Akrach (Rabat, Maroc) sur la qualité des ressources en eau, Revue Marocaine Civil, n68, 17 31.

6. Khattabi, H. (2002). These de doctorat « Interets de l'etude des parametres hydrogeologiques et hydrobiologiquespour la comprehension du fonctionnement de la station de traitement des lixiviats de la decharge d'ordures menageres d'Etueffont (Belfort, France) $\gg$, Soutenu le 25-02-2002.

7. Rodier, J. (1996). L'analyse de l'eau naturelle, eaux résiduaires, eau de mer, 8ème Edition, Dunod, Paris, 1383 p.

8. Tahiri, A.A., LaziriI, F., Yachaoui, Y., Jafari, S. \& Tahiria. H. (2014). Etude des polluants contenus dans les lixiviats issus de la décharge publique de la ville de Meknès. Européen Scientifique Journal. Déc. 2014, édition Vol 10, n³5, pp. 170-186.

9. Ntampou, X., Zouboulis, A.I. \& Samaras, P. (2006). Appropriate combination of physico chemical methods for the efficient treatment of landfill leachate, Chemosphere, 62, 2006, 722-730. 